\title{
Bioremediation of Liquid Waste Oil Through Bioreactor: A Case Study
}

\author{
HASMAWATY, HASMAWATY \\ Department of Industrial Engineering, Bina Darma University, Palembang - 30137, Indonesia.
}

http://dx.doi.org/10.12944/CWE.11.3.04

(Received: November 03, 2016; Accepted: December 07, 2016)

\begin{abstract}
This article aims to explain the process of bioremediation of waste oils and found the rate of reaction kinetics model microbes. Samples were taken from liquid waste petroleum oil and gas companies Prabumulih South Sumatra, Indonesia. The isolation process using a medium Zobell's and produces ten types of bacteria from the group Citrobacter sp, Micrococcaceaekarbon, and Flavobacterium sp. These bacteria's is used in wastewater treatment bioreactor which have characteristic as follow: operate semi-continuously, using aeration column that contain polyurethane foam, variation of air discharge is 2 and $6 \mathrm{ml} / \mathrm{sec}$, volume waste variation is 5 and 10 liters, 10 liters' isolate, $\mathrm{KNO}_{3}\left(640\right.$ gram) and $\mathrm{K}_{2} \mathrm{HPO}_{4}$ (10 gram) as nutrition. The results showed that when bioremediation process contains 10 liters' liquid waste, 10 liters' isolate, and $6 \mathrm{ml} / \mathrm{sec}$ air discharge, it can reduce $\mathrm{pH}$, specific gravity, $\mathrm{BOD}$ level, and the final weight of waste. Remediation process also increases the number of microbes, fatty oils and DO. Microbial maximum productivity is 59.50 with saturated concentration (Ks) at 3.25 , and its slope is 0.43 . Kinetics equation model following could be formulated as $\mu=0.43 \frac{s}{3.25+s}$.
\end{abstract}

Keywords: Bioremediation, Liquid waste oil, Bioreactor, South Sumatra, Indonesia.

\section{INTRODUCTION}

Indonesia is one of the oil producers and consumer's country. In 2014, Indonesia's oil production reached 289.878 million barrels'. Indonesia's oil wells spread in several areas, both on land and sea. In the Province of South Sumatra, one of the regions that have oil wells is Prabumulin Municipality. In this city, oil drilling activity has begun in the 1950 s by Pertamina, a state-owned Indonesian government, until today. In 2016, crude oil production in Prabumulih reaches 897.350 barrels per year ${ }^{2}$. The existence of drilling activity and processing of crude oil have led to Prabumulih as a region which highly vulnerable to environmental pollution caused by wastewater. The liquid waste can be derived from the residual drilling mud, oil droplets, and formation water. This incident not only disrupts the activities of residents who mostly work as farmer's rubber, but has the potential to worsen the quality of the environment.

Petroleum liquid waste containing aliphatic and aromatic hydrocarbon compounds that have a high molecular weight. In the aquatic environment, liquid waste petroleum can cause the diffusion of oxygen into the water. In the terrestrial environment, liquid waste petroleum can cause delays in the process of absorption of nutrients plant roots. Therefore, the liquid waste petroleum can cover the surface of roots under the soil surface. However, liquid waste oil can produce contamination of microorganisms in a location that makes petroleum hydrocarbons as a source of food and energy. In other words, the polluted environment of waste oils provides natural remedies to overcome 
environmental pollution caused by petroleum wastewater. This process is popularly known as bioremediation.

Bioremediation can be defined as a strategy, technique, methods, and approach to degrade pollutants and restore environmental quality using living organism, especially microorganism ${ }^{3-5}$. It is part of biotechnology which represents the convergence of biology, computer science, chemistry, physics, and engineering. These component technologies work in synergy, and they are each advancing rapidly. Biotechnology is an important component needed to successfully achieve the goal of sustainability. "Value-added" products from by-products/waste and novel technologies employing biotechnical principles represent areas where significant opportunities exist ${ }^{6}$. Bioremediation can clean unwanted substances from soil, water, air, and materials from industrial processing?.

To create genetically manipulated microorganisms, the metabolic pathways responsible for biodegradation of toxic compounds need to be understood, and the genes encoding the appropriate enzymes must be cloned and analyzed in detail ${ }^{8}$. Optimization of bioremediation processes generally requires the addition of inorganic materials (bio stimulation), such as utilizable sources of nitrogen, phosphorus, and oxygen ${ }^{9}$. In bio stimulation, nutrients are injected into the subsurface to stimulate and enhance the growth of microorganisms. The injected nutrients, like nitrogen and phosphorus, are essential to the growth and activity of microorganisms ${ }^{10}$.

There are several technologies in common use, divided broadly between ex situ and in situ methods. Ex situ technologies usually involve the construction of windrows or bio piles, either on site or at a remote location. In situ technologies are much less obtrusive, involve significantly fewer earthworks, but also require longer treatment times and suffer from a lack of control compared to ex situ technologies ${ }^{11}$. New bioremediation approaches are emerging based on advances in molecular biology and process engineering. Bioremediation continues to be the favored approach for processing biological wastes and avoiding microbial pathogenesis. Bioremediation may also play an increasing role in concentrating metals and radioactive materials to avoid toxicity or to recover metals for reuse ${ }^{12}$.

Bioremediation is still a popular and relevant topic, stimulating a vast number of important research ${ }^{13}$. It can clean unwanted substances from soil ${ }^{14-17}$ and water ${ }^{18-21}$. This research is designed to contribute to the scientific discussion about bioremediation, especially in the sectors of petroleum wastewater treatment.

\section{METHODS}

The study is conducting in two stages: isolation of samples (isolation, purification, selection, rejuvenation of isolates culture, and producing mix-culture) and bioremediation with continuous semi-batch process. We use completely randomized design as research design. It is consisting two factorial treatments: the volume of petroleum liquid waste $\left(R_{1}=\right.$ adding 5 liters' liquid waste for 100 liters at medium; $R_{2}=$ adding 10 liter's liquid waste for 100 liter's at medium) and air discharge as aeration $\left(Q_{1}\right.$ $=2$ liter's/second; $Q_{2}=6$ liter's/second). The total number of treatment combination is four unit, and each unit will be repeated twice so that it will produce eight experiments. We make bioreactor from the glass and consist two boxes. The first box has size $40 \times 40 \times 80 \mathrm{~cm}^{3}$. In the first box, we put the second box which size $28 \times 28 \times 40 \mathrm{~cm}^{3}$ (see, Figure 1). We treat this bioreactor with the continues semi-batch process with agitation speed reaches 120 rpm.

We measure several variables such as decreasing $\mathrm{pH}$ medium, specific gravity, BOD, the final weight of waste, increasing the waste solubility, and DO. We collected liquid waste sample from the waste container vessel owned by Pertamina located in Prabumulih Municipality. For isolation samples, we borrow laboratories facility at Laboratory of Microbiology, Faculty of Mathematics and Natural Sciences, Sriwijaya University. While bioremediation process carried out at the Laboratory of Chemistry, Chemical Engineering, Sriwijaya Polytechnic, Palembang. The final results of the analysis will be compared to the environmental quality standards (BML) is arranged in South Sumatra Governor Regulation Number 18/2005 on Standard Quality for Liquid Waste (see Table 1). 


\section{RESULT}

In the first step (isolation process), we get ten bacteria and labelling them as $A, B, C, D$, $E, F, G, H, I$, and J. All of them are bacillus, gramnegative, do not spore, and able to grow at medium are a part of Citrobacter sp, Micrococcaceaekarbon, and Flavobacterium. The addition of $\mathrm{KNO}_{3}$ and $\mathrm{K}_{2} \mathrm{HPO}_{4}$ simultaneously will decreasing the value of the specific gravity and the final weight of waste. The use of aeration in bioremediation processes greatly affect the effectiveness of mixed cultures of bacterial metabolism to degrade hydrocarbons. It is indicated by decreasing value of $\mathrm{pH}$ medium, specific gravity, the final weight of the waste, and BOD. For $\mathrm{pH}$ and $\mathrm{BOD}$ value, our data show that they are lower than threshold value as regulated by South containing petroleum waste (see Figure 2). They

Sumatra Governor Regulation Number 18/2005 on Standard Quality for Liquid Waste. At the same time, it increases the solubility waste, the number of microbes and fatty oils.

As shown in Table 2, the second treatment $\left(R_{2}\right.$ and $\left.Q_{2}\right)$ give better effect against microbes growth $\left(P_{m}=x_{m} / t_{m}\right)$ when compared to the first treatment $\left(R_{1}\right.$ and $\left.Q_{1}\right)$. For example, when we give substrate from five liter to ten liter, microbe productivity increased from 57.5 to 59.5 . In other word, the speed and acceleration of microbes growth rate are better when the provision of oxygen is proper. Based on saturated coefficient (Ks) at 3.25 , and its slope is 0.43 , kinetics equation model for bioremediation process could be formulated as $\mu=0.43 \frac{s}{3.25+s}$.

\section{DISCUSSION}

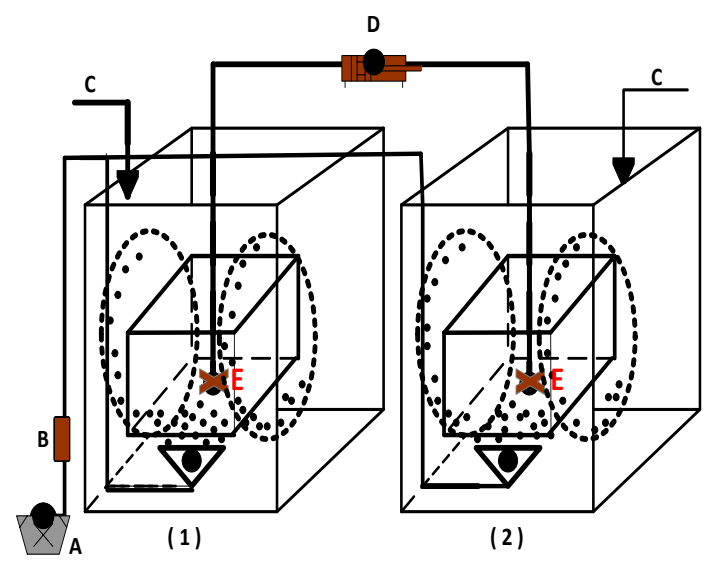

Note: A (air pump), B (flow meter), C (waste, nutrition, and isolate aquades), D (motor), and $\mathrm{E}$ (agitator)

Fig. 1: Mechanical bioreactor

Table 1: Standard quality for oil liquid waste

\begin{tabular}{|c|c|c|c|c|}
\hline \multirow[t]{2}{*}{ No } & \multirow[t]{2}{*}{ Parameter } & \multirow[t]{2}{*}{ Unit } & \multicolumn{2}{|c|}{$\begin{array}{c}\text { Type of standards } \\
\text { quality }\end{array}$} \\
\hline & & & I & II \\
\hline 1 & $\mathrm{pH}$ & unit & $6-9$ & $6-9$ \\
\hline 2 & $\mathrm{BOD}_{5}$ & $\mathrm{mg} / \mathrm{l}$ & 50 & 150 \\
\hline 3 & COD & $\mathrm{mg} / \mathrm{l}$ & 100 & 300 \\
\hline
\end{tabular}

The results of this study reinforce previous few prepositions in research on bioremediation, namely: first, environmental pollution, especially

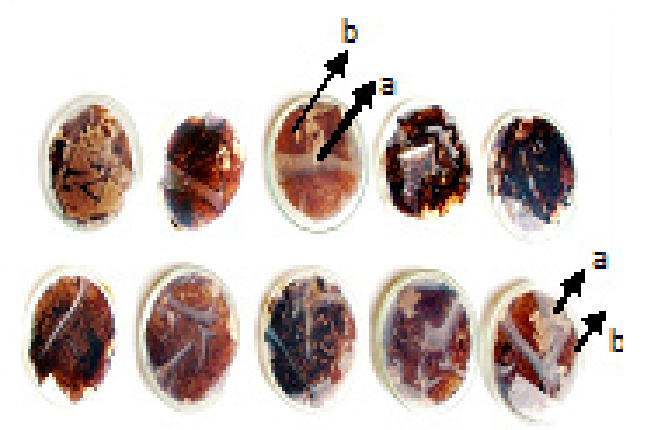

Note: a (bacteria colony), b (oil liquid waste)

Fig. 2: Stage 1 medium

Table 2: Microbes productivity

\begin{tabular}{lccccc}
\hline $\mathrm{Q}, 2 \mathrm{ml} / \mathrm{sec}$ & & & & & \\
5 (liter) & 10 (liter) & & & & \\
$\mathrm{X}_{\mathrm{m}}$ & $\mathrm{T}_{\mathrm{m}}$ & $\mathrm{P}_{\mathrm{m}}$ & $\mathrm{X}_{\mathrm{m}}$ & $\mathrm{T}_{\mathrm{m}}$ & $\mathrm{P}_{\mathrm{m}}$ \\
1.87 & 10 & 18.7 & 3.50 & 10 & 35.0 \\
$\mathrm{Q}, 6 \mathrm{ml} / \mathrm{sec}$ & & & & & \\
5 (liter) & 10 (liter) & & & & \\
$\mathrm{X}_{\mathrm{m}}$ & $\mathrm{T}_{\mathrm{m}}$ & $\mathrm{P}_{\mathrm{m}}$ & $\mathrm{X}_{\mathrm{m}}$ & $\mathrm{T}_{\mathrm{m}}$ & $\mathrm{P}_{\mathrm{m}}$ \\
5.75 & 10 & 57.5 & 5.95 & 10 & 59.5 \\
\hline
\end{tabular}


those derived from petroleum processing, can be solved by identifying and maximizing indigenous bacteria. Second, the use of nutrients in the right proportions can optimize bioremediation process. In the future, research on bioremediation should not only focus on to identify the type of bacteria that have the best ability to degrade petroleum waste. However, it needs to be directed to determine the types of compounds that occur after bioremediation, analyze microbes that prefer to use straight-chain hydrocarbon or a ring shape, and validated with toxicity tests.

\section{ACKNOWLEDGEMENT}

The research was funded by Center for Research, Development, and Regional Innovation South Sumatra Province (BALITBANGNOVDA) through contract number: 500.a/kptsbalitbangda/ 2013, 07 July 2013. Part of this paper has been presented at the seminar on "Assessment of Potential Industrial Development Zone in South Sumatra", organized by BALITBANGNOVDA in the Palembang City, 18 December 2013. Researchers would like to thanks to all the people who have helped this study.

\section{REFERENCES}

1. Badan Pusat Statistik. Environment Statistics of Indonesia 2015. (Badan Pusat Statistik, 2015). doi:10.1017/CBO9781107415324.004

2. BPS Kota Prabumulih. Prabumulih Municipality in Figures 2016. (BPS Kota Prabumulih, 2016).

3. Naseri, M., Barabadi, A. \& Barabady, J. Bioremediation treatment of hydrocarboncontaminated Arctic soils: influencing parameters. Environmental Science and Pollution Research 21, 11250-11265 (2014).

4. Atlas, R. M. \& Cerniglia, C. E. Bioremediation of petroleum pollutants. International Biodeterioration and Biodegradation 45, 332-338 (1995).

5. Crawford, R. L. in Bioremediation: principle and application (eds. Crawford, R. L. \& Crawford, D. L.) 1-2 (Cambridge University Press, 1996).

6. Englande, A. J. \& Jin, G. Application of biotechnology in waste management for sustainable development. Management of Environmental Quality: An International Journal 17, 467-477 (2006).

7. Rowley, W. R. Biotechnology overview. Foresight 4, 4-13 (2002).

8. Pohland, F. G. \& Tedder, D. W. Emerging Technologies in Hazardous Waste Management V An Overview. 1-8 (1995).

9. Crawford, R.L.\&Rosenberg, E. Bioremediation. The Prokaryotes: Applied Bacteriology and Biotechnology (Springer Berlin Heidelberg,
2013). doi:10.1007/978-3-642-31331-8

10. Drell, D., Palmisano, A. \& Broido, M. Ethical, Legal, and Societal Implications of Bioremediation. Natural Resources \& Environment 13, 533-536 (1999).

11. Gillespie, I. M. M. \& Philp, J. C. Bioremediation, an environmental remediation technology for the bioeconomy. Trends in Biotechnology 31, 329-332 (2013).

12. Bonaventura, C. \& Johnson, F. M. Healthy environments for healthy people: bioremediation today and tomorrow. Environmental Health Perspectives 105, 5-20 (1997).

13. Puglisi, E., Trevisan, M., Grotenhuis, T. \& Adrian, L. EUROSOIL 2012 bioremediation session: preface to special issue. Biodegradation 24, 451-453 (2013).

14. Hanson, K. G., Nigam, A., Kapadia, M. \& Desai, A. J. Bioremediation of crude oil contamination with Acinetobacter sp. A3. Current Microbiology 35, 191-193 (1997).

15. Tissot, P. Calorimetric study of the bioremediation of a polluted soil. Journal of Thermal Analysis and Calorimetry 57, 303-312 (1999).

16. Margesin, R., Hämmerle, M. \& Tscherko, D. Microbial activity and community composition during bioremediation of dieseloil-contaminated soil: Effects of hydrocarbon concentration, fertilizers, and incubation time. Microbial Ecology 53, 259-269 (2007).

17. Lin, $X$. et al. Changes in microbial 
populations and enzyme activities during the bioremediation of oil-contaminated soil. Bulletin of Environmental Contamination and Toxicology 83, 542-547 (2009).

18. Bhadbhade, B. J., Sarnaik, S. S. \& Kanekar, P. P. Bioremediation of an Industrial Effluent Containing Monocrotophos. Current Microbiology 45, 346-349 (2002).

19. Dash, H. R., Mangwani, N., Chakraborty, J., Kumari, S. \& Das, S. Marine bacteria: potential candidates for enhanced bioremediation. Applied Microbiology and Biotechnology 97,
561-571 (2013).

20. Ojumu, T. V, Bello, O. O., Sonibare, J. A. \& Solomon, B. O. Evaluation of microbial systems for bioremediation of petroleum refinery effluents in Nigeria. African Journal of Biotechnology 4, 31-35 (2005).

21. Kumar, R., Singh, P., Dhir, B., Sharma, A. K. \& Mehta, D. Potential of Some Fungal and Bacterial Species in Bioremediation of Heavy Metals. Journal of Nuclear Physics, Material Sciences, Radiation and Applications 1, 213-223 (2014). 